\title{
Development of Wireless Kundt's Tube Kit as an Experiment Tool in Determining Speed of Sound and Proposing for a Hearing Test
}

\author{
https://doi.org/10.3991/ijoe.v18i02.23267 \\ Nadi Suprapto $\left.{ }^{1}{ }^{凶}\right)$, Achmad Ichsan Rosyidi ${ }^{1}$, Husni Mubarok ${ }^{2}$, Alif Syaiful Adam ${ }^{3}$ \\ ${ }^{1}$ Universitas Negeri Surabaya, Jawa Timur, Indonesia \\ ${ }^{2}$ National Taiwan University of Science and Technology, Taipei, Taiwan \\ ${ }^{3}$ Universitas Negeri Malang, Jawa Timur, Indonesia \\ nadisuprapto@unesa.ac.id
}

\begin{abstract}
As a part of contextual learning, laboratory activity supports the physics concept attainment. The everyday physics in real life occur from the concept of sound, by hearing a sound every day. For further application, the sound wave concept needs to be understood by a particular experiment. For gaining that purpose, this study develops Wireless Kundt's Tube kit. The study has two essential purposes: determining sound speed through the kit and examining the kit as an alternative for a hearing test. The study utilized the ADDIE research design: Analyze-Design-Develop-Implement-Evaluate stages. Specifically, the apparatus bravely brands as wireless Kundt's Tube use Bluetooth connection to integrate the smartphone's central apparatus and have easier accessibility to the students' gadget. This final kit has tried to students in 11th grade of a senior public school in East Java, Indonesia, to demonstrate their feedback. This kit passed the media and content validity as part of learning media development. The study gained a sound speed of $303.03 \mathrm{~m} / \mathrm{s}$ and proposed the hearing test's idea to replace the turning fork function in a traditional test. It means Wireless Kundt's Tube can apply to the following instruction process as the motivational part for physics learning and a hearing test.
\end{abstract}

Keywords—resonance tube, Kundt's Tube, learning media

\section{Introduction}

\subsection{Kundt's Tube on educational purpose}

As a common phenomenon in daily life, sound can be tracked easily in the hearing process. However, it is difficult to observe a visual thing, both the transferring process and the vibration, as the sound source. As the effect of vibration, sound can be heard as the longitudinal wave resonance to the air around consists of the compressed region that travel through the air. Furthermore, the soundwave travels through the air as the disturbance of the air pressure along the wavelength direction [1], and for this reason, the wave should be travel at a particular speed. The sound wave travels at different 
speeds depending on the temperature and air pressure [2]. At $0^{\circ} \mathrm{C}$ temperature and 1atmosphere air pressure, sound travels at a speed of $331 \mathrm{~m} / \mathrm{s}$. For this speed determination, Kundt's Tube is the appropriate apparatus to measure sound speed [3]. This prop can visualize the sound wave in a transparent glass tube from the Styrofoam Granules effect. It means this apparatus has the beneficial thing to take the visible wave to the observation moment. The sound waves that travel in the glass tube make the granules form in a particular pattern - next described as the sound wave pattern. The granules will assemble in node with a relative still position and attractive movement in antinode. Therefore, it is possible to visualize the sound wave and determine the nodes and antinodes once [4].

For educational purposes, physics concept attainment on sound waves appears at the senior high level. Hence, the introductory physics laboratory should use Kundt's tube experiment to describe the sound physics concept and determine sound speed. Using this apparatus as learning media gives the students opportunities in contextual and meaningful-direct experience [5]. In that activity, students develop their knowledge due to the thinking process, thinking skill, and performance skill on the direct interaction of the learning source from the scientific process [6, 7]. Thus, learning media is crucial for detailed information in conceptual gaining, especially in abstract physics concepts. It can optimize as much sense in the instructional process thought mostly gained from observation and hearing processes. Afterwards, as the responsible person in the studying process in class, the teacher should have the capability to manage the learning media for clear and meaningful learning objections [8].

In the Covid-19 pandemic era, the predetermined lesson plan cannot apply to students as the previous condition, and it gets in another way for instruction activities on formal education at all school levels. Pandemic risk can be avoided by physical interaction decreasing and social interaction on teacher-students or between students in the classroom. As a solution, they can transfer that interaction to the virtual environment like an available online video conference. Nevertheless, the most problematic issue for physics learning state on experiment activity. Unavailable apparatus for instructional objectives at home make this activity almost impossible to do. This research tries to answer this challenge by optimizing the student's smartphone as the most potential gadget to use as an alternative.

\subsection{Hearing test}

A hearing test is a screening procedure to evaluate how well a person can hear a voice. This examination is essential to detect whether there is hearing loss earlier. Hearing tests are performed to detect possible hearing loss and ensure that the hearing sense is appropriately functional. Moreover, a hearing test determines the hearing loss and the severity of the disturbance. Ear nose throat (ENT) specialists and audiologists can perform hearing tests. To evaluate the function of the hearing sense, the several common ways are: 
1. Pure tone audiometry (pure tone audiometry): In this hearing test, a patient will be paired with headphones, and the audiologist will ask him to press an available button if he hears a sound from the headphones.

2. Test the tuning fork: This hearing test uses a tuning fork to determine how a patient responds to sounds and vibrations around the ear. With the help of a tuning fork, the tester will determine whether the patient has hearing loss in one or both ears.

3. Brainstem response evaluation: This hearing test aims to evaluate the auditory nerve and brain's ability to receive and respond to a sound. This examination is performed by placing electrodes into the patient's ear canal and scalp surface. The electrodes will measure the brain's electrical activity while responding to the sound sent through the earphones. This test can detect whether there is a hearing loss or sensorineural type deafness.

This study develops the experiment apparatus that includes its validity and effectivity, subsequently called Wireless Kundt's Tube. This prop can operate wireless and use the students' smartphone devices. Therefore, students get laboratory activity in an unlimited range if the available internet connection. They can then observe the sound pattern in the standing wave as the resonance effect to gain the same objection as to the previous condition before the pandemic. In addition, the Wireless Kundt's Tube can be used as a hearing test to measure hearing ability and hearing loss.

\section{$2 \quad$ Method}

\subsection{Development design}

This study uses ADDIE development design and consists of Analyze, Design, Development, Implement and Evaluate stages [5]. This apparatus was designed in a range of February-June 2020, which the pandemic appears globally. After the design and building process, the prototype appears to the students in a public high school in Ponorogo, East Java, Indonesia, where the actual online learning process occurs. Afterwards, the prototype has many developments based on the validation from the expert and a limited test. A whole process in this development shows in Figure 1. 


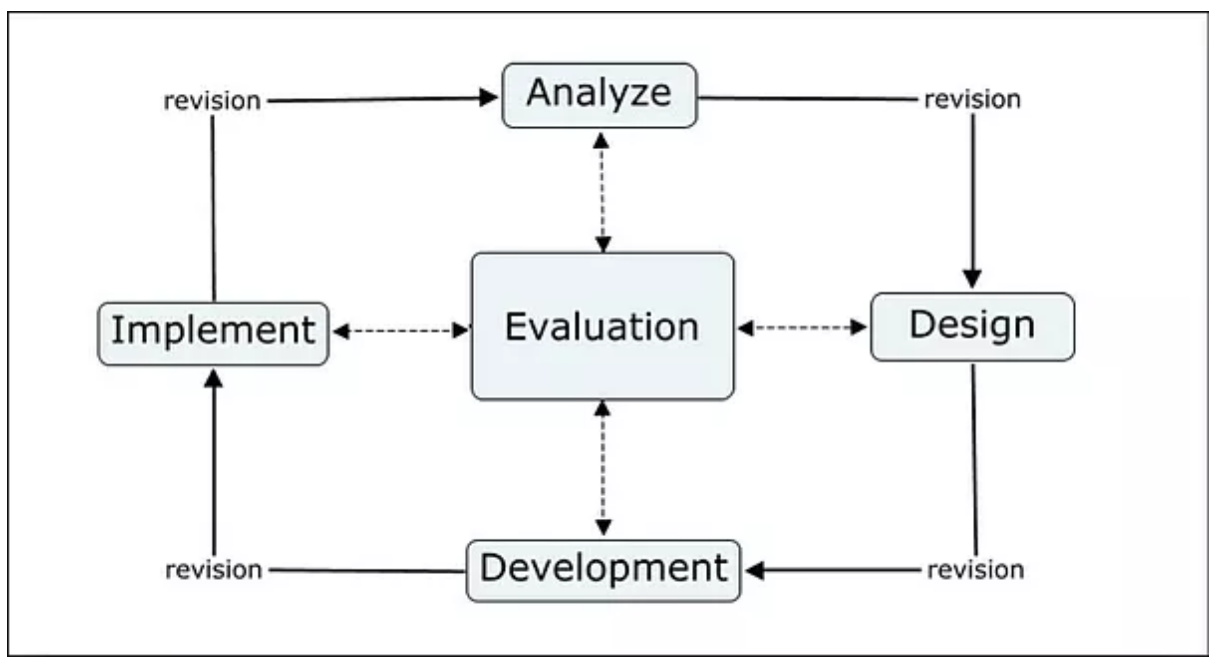

Fig. 1. Research stages [5]

\subsection{Data analysis}

To ensure this apparatus's validation, many validity checks done by the expert and students' responses collect as a limit test. The media's validity shows the Wireless Kundt's Tube's appropriateness, scored by media expert, physics content expert, and contextual practitioner in school. After passing the experts' validity, these media were implemented from the actual design of online instruction. Fifteen random eleventhgrade students in a public Senior High School in Ponorogo choose to pass this exclusive test set. Afterwards, the students show their responses through questionnaires. All the validity and students' responses instruments use a Likert scale [9]. Wireless Kundt's Tube score result will be categorized as valid and effective if more than $60 \%$.

\section{Results and discussion}

Every development stage follows Analyze, Design, Development, Implement, and Evaluate stages as the fundamental stages in ADDIE.

\subsection{Analyze}

The observation process needs to find the lack of physics learning in the pandemic era and the potency in the school learning environment. That process finds the students' saturated physics concept learning as the consequence of learning physics only on the formula and textual approach, focusing on physics. It triggered low students' involvement in physics and gained low learning achievement. Besides, there is no regular experiment activity to give the standing wave's visual vision and data on reso- 
nance phenomena. Further findings show no relating apparatus to measure sound speed as the second-grade physics topics on a high school level.

As the national curriculum analysis, the sound wave appears on basic competence (KD) 4.10 as the skill aspect and produce the performance assessment. That competence contains the experiment activity on sound wave and light, presenting the experiment result and physical meaning. Based on that basic competence, students should have the experimental activity.

\subsection{Design}

Kundt's Tube development have everyday use to determine the speed of sound in the introductory physics laboratory. This prop's previous design is preliminary to develop wireless integration, which could be this apparatus's novelty. The previous design consists of three components [10]. There are:

- $\mathrm{AFG}$ as a frequency generator

- Speaker as the sound wave source

- Transparent glass tube as the resonance tube

AFG connected to the speaker with conductorial wire. A speaker located at the end of the glass tube and a sliding piston at another end makes the piston replaceable for the tube's length as the manipulative variable in an experimental setting. Along part of the tube, fill with Styrofoam granules to visualize the standing wave as the resonance phenomena.

\subsection{Develop}

Many previous apparatuses Kundt's Tube used to the basic design of Wireless Kundt's Tube $[11,12,13,14,15]$. That prop modified to gain wireless support to the broader range operating, use many components such as smartphone device (IOS or Android), Bluetooth sound receiver, mini amplifier, and free access smartphone software 'physics toolbox sensor suites' (manufactured by Vieyra Software). The whole Wireless Kundt's Tube designs are shown in Figure 2. 


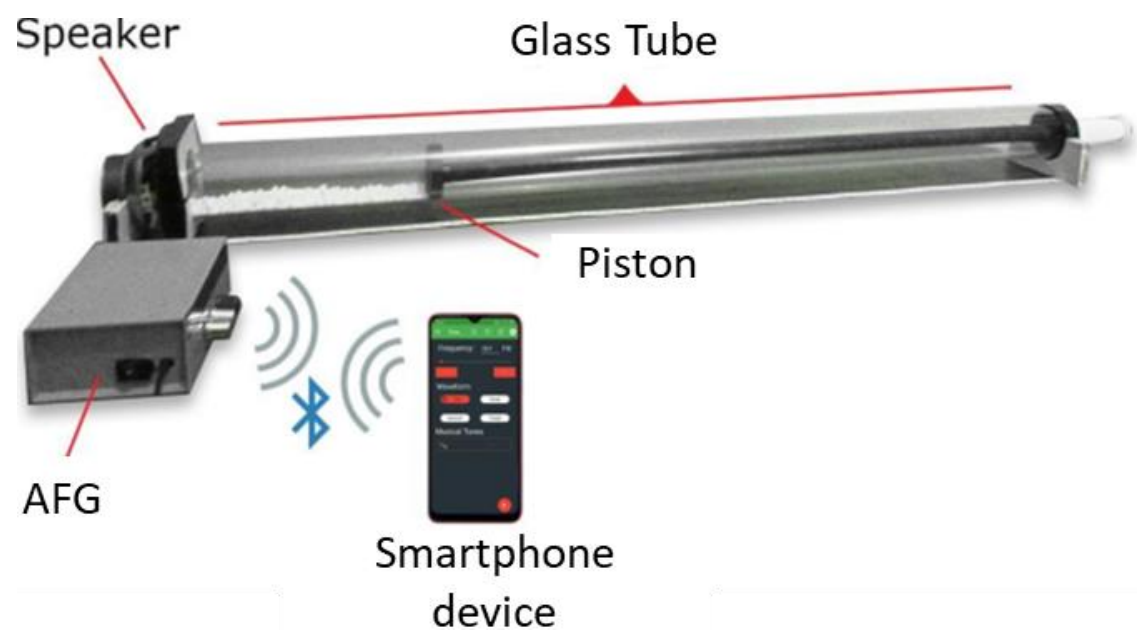

Fig. 2. Wireless Kundt's Tube design

\subsection{Implement}

The valid media were trying to implement the actual situation by demonstrating this prop to students. As the pandemic, this stage passed with them online through video conference for follows the government suggestion to avoid the pandemic effect, which the instruction process from the beginning time of pandemic in online or called SFH (Study from Home). The learning processes do in a WhatsApp group of students, and the instrument sends to the students through it. That instrument involves the Wireless Kundt's Tube manual book, apparatus introduction video, data collecting video, and student worksheet. For gaining the students' responses in the instructional process, the students' responses questioners were shared with the student. That responses consist of two aspects, presentation and content. The positive students' responses show in Figure 3. 


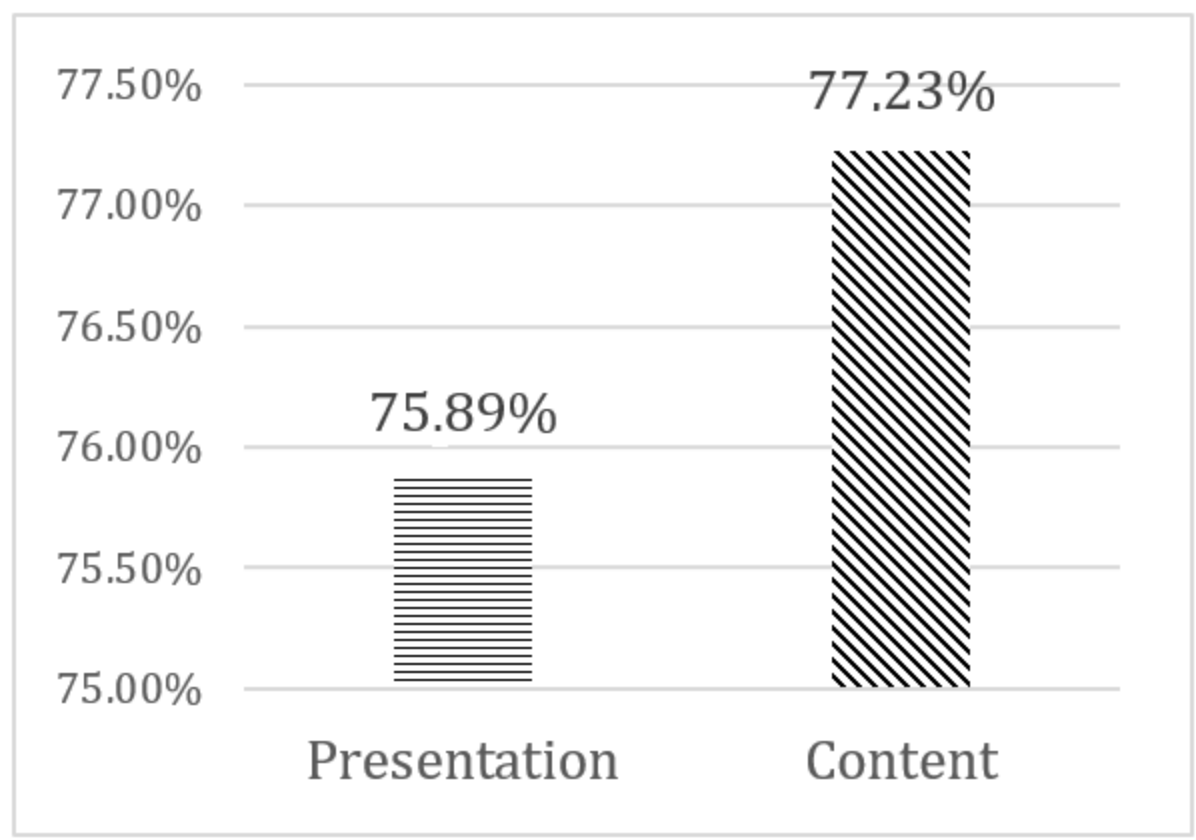

Fig. 3. The percentage of every aspect of students' responses after the Wireless Kundt's Tube demonstration

Based on Figure 3, students' responses on every aspect have an average of $76.57 \%$. Wireless Kundt's Tube effectively uses and integrates it into physics instruction, especially for grabbing attention due to the motivational process.

After the function of motivational purpose, this prop uses to determine the sound speed in a resonance set, and so does the standing wave. The experiment process has passed the validation process from media experts. The experiment process manipulates the air column's length in a glass tube with the control of first resonance in every length. Then, the response variable is the frequency needed to gain the first resonance. As the sample, the data result is shown in Table 1.

Table 1. The result data of Wireless Kundt's Tube

\begin{tabular}{|l|c|c|c|c|}
\hline No & Length of the air column $(\mathbf{m})$ & Frequency $(\mathbf{H z})$ & Wavelength $(\mathbf{m})$ & Speed of Sound $(\mathbf{m} / \mathbf{s})$ \\
\hline 1. & 1.00 & 81 & 4 & 324.0 \\
\hline 2. & 0.90 & 91 & 3.6 & 327.6 \\
\hline 3. & 0.80 & 103 & 3.2 & 329.6 \\
\hline 4. & 0.70 & 118 & 2.7 & 330.4 \\
\hline 5. & 0.60 & 132 & 2.4 & 316.0 \\
\hline
\end{tabular}

The data in Table 1 can be transformed into a graph to gain more information about the relation between the length of the air column and frequency or even gain the speed of sound based on the gradient information. 
Based on the graph in Figure 4, the speed of sound can be determined by the gradient value through 1 divided by the gradient [16]. From its determination, the speed of sound is $303.03 \mathrm{~m} / \mathrm{s}$ with a data consistency of $98.21 \%$. This value is enough for the instructional purpose at the high school level. The more important thing is that this result can determine the relationship between the wavelength and frequency in resonance phenomena.



Fig. 4. Plotting of length of the air column and frequency

\subsection{Evaluate}

The evaluation appears in every part of the stages and has an objection to correcting a fault based on the expert advice or participants. From the need analysis, opportunities were observed to gain the potential view and look at the inappropriate things in the previous learning process. This observation makes the best decision for media development. The expert suggestions and previous research appear to take the best decision and idea for the apparatus developments in the design process. Thus, the final product represents the actual needs of the instructional situation. This development focuses on increasing the past prop's flexibility with up-to-date technology integration to produce the prototype. Then, the media is validated by the media and content expert and the teacher as the genuine school environment practitioner. Based on their suggestions, the apparatus should improve storage and data collecting efficiency, but it has a positive percentage of $77.38 \%$ as the final validity score. In the next step, students' responses questioner uses to guide for final evaluation and need more improvement on sound wave visualization from Styrofoam granules, cannot look clearly in the video. This problem is certainly solved due to the media properness. As the last statements, this apparatus still has the best situation for use, has more visible to ob- 
serve the sound wave pattern directly, and needs steady and save space to store the media for longer.

\subsection{Wireless Kundt's Tube kit for a hearing test}

As a hearing test, many parts of the Wireless Kundt's Tube are an alternative prop to ensure the sense of hearing. From the data in Table 1, the sound generator of this apparatus state audio sonic frequency - safe to use as the hearing test. An audiometric hearing test aims to evaluate the hearing ability and detect hearing problems early on or as the hearing routine check. Hearing loss is a condition when a person cannot hear part or all of a sound through one or both ears. People with mild hearing loss may still be able to communicate well. However, severe hearing loss can cause deafness, and it certainly disturbs the sufferer's quality of life and creates difficulties in communicating.

A tuning fork test is an examination procedure used to evaluate hearing loss. This test can be done using the Rinne Test, the Weber Test, and the Schwabach Test. An assessor will use a $512 \mathrm{~Hz}$ tuning fork from the Wireless Kundt's Tube's sound generator to gain the patient's response to sounds and vibrations around the ear. The apparatus has an extra extension on the glass tube after the speaker, as shown in Figure 5.

For the Schwabach test integration, a tester will vibrate a sound generator and place it on the mastoid bone behind the ear. If a patient cannot hear the sound anymore, the tester will immediately move the sound generator to another part. Besides, the haring test can perform in the Weber test. The tester will ring a sound generator and place it in the head's centre on the forehead, over the head, or between the nose and cheeks. Furthermore, the third method gained from the Rinne test: The tester will vibrate the sound generator with a frequency of $512 \mathrm{~Hz}$ and place the head over the mastoid process. The patient will be instructed to listen to the sound until nothing is heard and raise a finger when the sound begins to fade. After that, the tester will immediately move the sound generator to the person's ear whose hearing is normal and compare the hum they hear.
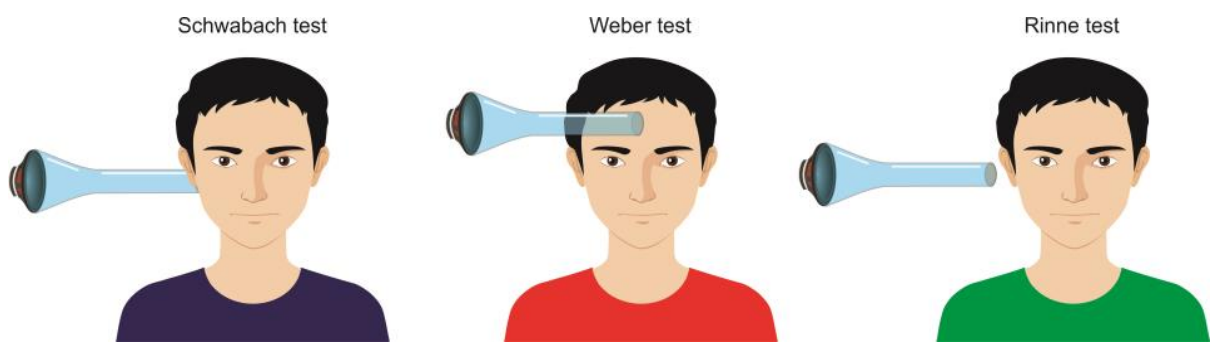

Fig. 5. Apparatus position on each hearing test

Wireless Kundt's Tube apparatus on final development has a hybrid function on educational purpose and hearing test. However, for an objective tool to generate hearing health, it needs to practice for further development. Afterwards, this potential function can be developed for other educational purposes, used to hearing check on 
Paper-Development of Wireless Kundt's Tube Kit as an Experiment Tool in Determining Speed of...

another subject. In discussing ear structure and its health, this apparatus could demonstrate the student's hearing test.

\section{Conclusion}

Based on a whole stage on media development, many results were gained in this particular research: (1) Wireless Kundt's Tube apparatus was proper for learning media. Media and content validity gain a percentage of $77.38 \%$ in valid category by the experts, which means it fills the proper criteria for learning design. (2) The effectivity gains a percentage of $76.57 \%$ in a suitable category from the students' responses. (3) The data consistency is $98.21 \%$ due to data collecting to determine the speed of sound. Wireless Kundt's Tube can rapidly improve the subsequent integration to the learning design or alternative hearing test. For the successive hearing test, the extension part of the glass tube is made in a narrowed glass tube. Moreover, this apparatus is the alternative of tuning fork used in the Rinne Test, the Weber Test, and the Schwabach Test to measure hearing ability and hearing loss.

\section{$5 \quad$ References}

[1] Serway, R. A. \& Jewett, J. W. (2014). Physics for scientists and engineers with modern physics (9th Ed.). Boston: Cengage Learning.

[2] Admoko, S., \& Supriyono, S. (2016). Workshop peningkatan kemampuan merancang kegiatan laboratorium berorentasi pada pendekatan saintifik bagi guru fisika Sidoarjo. Jurnal Penelitian Fisika dan Aplikasinya (JPFA), 6(34). 34-42. https://doi.org/10.26740/jp fa.v6n1.p34-42

[3] Sakamoto, S., Asakura, T., Ueno, K., Sakimoto, Y., Satoh, F., \& Tachibana, H. (2006). Visualization of acoustic resonance phenomena using Kundt's dust figure method. The Journal of the Acoustical Society of America, 120(5), 3070-3070. https://doi.org/10.1121/ 1.4787366

[4] Stadler, E. M., \& García, M. J. E. (2019). Experiments with Kundt's tube. Journal of Physics: Conference Series. 1287: 012022-1 - 012022-8. https://doi.org/10.1088/1742-6596/128 $\underline{7 / 1 / 012022}$

[5] Adam, A. S., \& Suprapto, N. (2019). One-stop physics e-book package development for senior high school learning media. International Journal of Emerging Technologies in Learning, 14(19). 150-158. https://doi.org/10.3991/ijet.v14i19.10761

[6] Rahmawati, P. E. A., \& Budingarti, H. (2018). Penerapan Model Pengajaran Langsung pada Materi Gerak Harmonik Sederhana untuk Meningkatkan Hasil Belajar Siswa. Jurnal Inovasi Pendidikan Fisika, 7(1). 55-59. https://doi.org/10.31764/orbita.v5i1.896

[7] Kustijono, R. (2011). Implementasi student centered learning dalam praktikum fisika dasar. Jurnal Penelitian Fisika dan Aplikasinya (JPFA), 1(2), 19-32. http://dx.doi.org/10.267 40/jpfa.v1n2.p19-32

[8] Ariyani, F., Nayana, T., Saregar, A., Yuberti, Y., \& Pricilia, A. (2018). Development of photonovela with character education: As an alternative of physics learning media. Jurnal Ilmiah Pendidikan Fisika Al-Biruni, 7(2). 227-237. https://doi.org/10.24042/jipfalbiruni.v7 $\underline{\mathrm{i} 2.3072}$

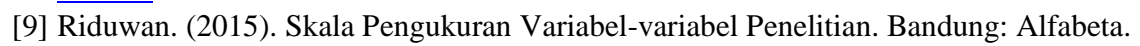


Paper-Development of Wireless Kundt's Tube Kit as an Experiment Tool in Determining Speed of...

[10] Nursulistiyo, E. (2018). Design and development of multipurpose Kundt's tube as physics learning media. Journal of Physics: Conference Series, 983(1). 012011-1 - 012011-6. https://doi.org/10.1088/1742-6596/983/1/012011

[11] Estupiñán, A., Ortiz, R., Duarte, Á., Sanchez, J., \& Arciniegas, J. (2018). Experimental and numerical study for the representation of standing waves in a Kundt's tube. Physics of Wave Phenomena, 3(2), 6-11.

[12] Hellesund, S. (2019). Measuring the speed of sound in air using a smartphone and a cardboard tube. Physics Education, 54(3), 035015-1 - 035015-5. https://doi.org/10.1088/1361$\underline{652 / \mathrm{ab} 0 \mathrm{e} 21}$

[13] Papacosta, P., \& Linscheid, N. (2016). An inexpensive and versatile version of kundt's tube for measuring the speed of sound in air. The Physics Teacher, 54(1), 50-51. https://doi .org/10.1119/1.4937975

[14] Barrett, R. P. (1980). Kundt's tube and an air track blower. The Physics Teacher, 18(7), 542-542. https://doi.org/10.1119/1.2340600

[15] Jaafar, R., Ayop, S. K., Ismail@ Illias, A. T., Hon, K. K., Daud, A. N. M., \& Hashim, M. H. (2016). Visualization of harmonic series in resonance tubes using a smartphone. The Physics Teacher, 54(9), 545-547. https://doi.org/10.1119/1.4967895

[16] Lutfiyah, A. Adam, A. S., Suprapto, N., Kholiq, A. \& Putri, N. P. (2018). Correction factors in determining speed of sound among freshmen in undergraduate physics laboratory. Journal of Physics: Conference Series. 997(1). 012024-1 - 012024-6. https://doi.org/10.108 $\underline{8 / 1742-6596 / 997 / 1 / 012024}$

\section{Authors}

Nadi Suprapto is an Associate Professor and Researcher of Physics Education, Universitas Negeri Surabaya, Indonesia.

Achmad Ichsan Rosyidi is an alumnus of undergraduate student from Physics Education Program in Physics Department, Universitas Negeri Surabaya, Indonesia.

Husni Mubarok is a doctoral student on Graduate Institute of Digital Learning and Education, College of Liberal Arts and Social Sciences, National Taiwan University of Science and Technology, Taiwan.

Alif Syaiful Adam is a master student on Graduate Program of Physics Education, Universitas Negeri Malang, Indonesia.

Article submitted 2021-04-13. Resubmitted 2021-11-15. Final acceptance 2021-11-17. Final version published as submitted by the authors. 